\title{
WATER-SOLUBLE FACTORS IN THE NUTRITION OF OXYRRHIS MARINA
}

\author{
By M. R. Droop \\ The Marine Station, Millport, Scotland
}

(Text-figs, I-8)

Oxyrrhis marina Dujardin is a non-photosynthetic dinoflagellate whose obvious mode of nutrition is phagotrophy. The method of feeding was described by Barker (1935). It is an extremely euryhaline and hardy organism and is apparently very successful in brackish habitats such as supralittoral rock pools and ditches (Droop, I953a). Owing to the ease with which it can be cultivated Oxyrrhis is a choice for the initial study of phagotrophy among the predominantly plant-like Dinoflagellata.

Axenic cultures (i.e. cultures free from other organisms of any kind) are required for nutritional studies, but they are not often easily established when the subject is phagotrophic. Oxyrrhis was no exception, despite the ease with which it can be kept in the laboratory. Bacteria-free cultures of a Finnish race were established in I95I (Droop, I953 $b$ ), but there then appeared to be a requirement for a living food organism such as a yeast or alga. Dr J. J. A. McLaughlin (Haskins Laboratories, New York, personal communication) succeeded, however, with axenic cultures of another strain in 1954, but unfortunately was not in a position to pursue the matter.

Dr McLaughlin's media contained, in addition to sources of water-soluble nutrients, such substances as soya meal, corpus luteum extract, cream, and beef serum in an attempt to meet the suspected fat requirement. These ingredients proved difficult to handle and unreliable in Dr McLaughlin's experience and, moreover, in my hands they entirely failed to support axenic growth. The first reliably successful axenic cultures at Millport were obtained in I955 with a medium supplemented with $4 \mathrm{ml}$./1. of neutralized, strained but unfiltered, lemon juice. At a later date the juice was replaced by a carbon tetrachloride extract of the rind, which has the advantage of being composed entirely of fat-solubles. Isolation and identification of this fat-soluble 'lemon factor' is not completed, and will not be discussed further in this paper, which is concerned with water-soluble components of the medium.

\section{MATERIALS AND METHODS}

The strain of Oxyrrhis referred to as the Finnish race (Millport No. I8; Culture Collection of Algae and Protozoa, the Botany School, Cambridge, No. LB II $33 / \mathrm{I}$ ) and used in these experiments was isolated by myself from 
a supra-littoral pool at Tvärminne, Finland, in I951. To obtain axenic cultures, monoxenic ones, in which the food organism was an obligate phototroph (Nannochloris oculata), were simply incubated in the dark with lemon juice. Tests showed these cultures to be free of algae after two transfers.

Stocks were maintained in medium E 6 (Provasoli, McLaughlin \& Droop, I957) supplemented with the lemon factor. ${ }^{1}$ The extract referred to as ' $\mathrm{LF}$ ' henceforth is a Sohxlet carbon tetrachloride extract of autoclaved, then ovendried $\left(70^{\circ} \mathrm{C}\right)$ lemon rind, concentrated to ro ml. per lemon, and kept wellstoppered in complete darkness. LF was shaken up with the medium beforehand and the solvent driven off on autoclaving, leaving the extractives in fine suspension. Alternatively, in later experiments not concerned with carbon nutrition, LF was administered from ethanolic solution, which obviated shaking.

Glassware was cleaned with 'Lux' then chrome-sulphuric acid followed by repeated rinsing in tap, then distilled, water. Synthetic media were prepared from AR quality chemicals with glass-distilled water. Approximately $0.6 \mathrm{ml}$. of inoculum was used to start experimental cultures of $6 \mathrm{ml}$. capacity in $15 \times 150 \mathrm{~mm}$ Pyrex test-tubes plugged with cotton-wool (aluminium caps in some experiments as a check against chemical contamination from cottonwool). Cultures were incubated in darkness at $22^{\circ} \mathrm{C}$. Elimination of carryover from the complex to simpler media in the experiments was effected by serial transfers, ten being regarded as sufficient for this purpose. A bacteriological peptone or medium E 6 was used for frequent routine sterility tests, a necessary precaution since phagotrophy can obscure bacterial contamination in cultures. Cell counts were made in a chamber $0.67 \mathrm{~mm}$ deep with the aid of a squared eyepiece graticule, and are expressed as cells per $\mathrm{mm}^{3}$ to the nearest whole number.

\section{DEVELOPMENT OF A DEFINED BASAL MEDIUM}

The first step in simplifying the stock medium E 6 was to replace the liver extract and Bacto Tryptone by $3 \mathrm{mg} / 1$. tryptophane, $400 \mathrm{mg} / 1$. Bacto Vitaminfree Casamino Acids (VFC) and $3 \mathrm{ml}$./ 1 . of the B vitamin mixtures, D 7, 8 and 9 (Table $\mathrm{I}$ ). Yield of cultures then increased to over roo cells per $\mathrm{mm}^{3}$ and was maintained thus over many transfers.

The next stage was to replace VFC by synthetic mixtures of amino-acids (AA I-AA V, Table I) with, however, only limited success, as the aminoacids gave a reduced yield which was restored by $200 \mathrm{mg} / \mathrm{l}$. VFC. It later transpired that the new medium lacked metabolizable carbon.

\footnotetext{
1 I 1 . of supplemented E6 contains: Oxo Liver Infusion (L 25), $250 \mathrm{mg}$; Bacto Tryptone, $250 \mathrm{mg}$; glucose, $250 \mathrm{mg}$; soil extract, $\mathrm{I2} .5 \mathrm{mg} ; \mathrm{KNO}_{3}, 50 \mathrm{mg} ; \mathrm{K}_{2} \mathrm{HPO}_{4}, 5 \mathrm{mg} ; \mathrm{MgSO}_{4} 7 \mathrm{H}_{2} \mathrm{O}$, $5 \mathrm{mg}$; LF, $3 \mathrm{ml}$; natural sea water, $500 \mathrm{ml}$.
} 
Soil extract could be omitted and artificial solutions SW I and SW 2 (Table 6; Provasoli et al., I957) and a dispersing agent for LF, sodium taurocholate, could substitute for the natural sea water in $\mathrm{E} 6$, provided the liver infusion was kept. But with liver infusion and Tryptone replaced as above neither natural sea water nor soil extract were replaceable by the buffered trace metal solutions usually used for this purpose (e.g. TM2 and the buffer tris(hydroxymethyl)aminomethane (TRIS) as used in $\mathrm{S}_{3} 6$ and $\mathrm{S}_{46}$, etc. (Provasoli et al., 1957).

An alternative to the obvious hypothesis that unknown growth factors were being supplied by both soil extract and natural sea water was that the mixtures replacing them were toxic. Both TRIS and EDTA (ethylenediaminetetraacetic acid, the chelating agent in TM2) were known to be toxic to some organisms, and the possibility that $\mathrm{TM}_{2}$ was unbalanced could not be ruled out. So indeed it proved, for eventually soil extract and natural sea water were successfully replaced by a synthetic medium containing neither TRIS nor EDTA.

\section{TABLE 1. S49, PARTIALLY DEFINED 'UNTAILORED' MEDIUM}

(LF being the only undefined component)

\begin{tabular}{|c|c|}
\hline $\mathrm{SW} \mathrm{I}^{\star}$ & $250 \mathrm{ml}$. \\
\hline $\mathrm{SW} 2^{\star} \star$ & $5 \mathrm{ml}$. \\
\hline TM IIB* & IO $\mathrm{ml}$. \\
\hline Glycylglycine & $500 \mathrm{mg}$ \\
\hline L-Histidine & $200 \mathrm{mg}$ \\
\hline $\mathrm{K}_{2} \mathrm{HPO}_{4}$ & Io $\mathrm{mg}$ \\
\hline $\mathrm{KNO}_{3}$ & $100 \mathrm{mg}$ \\
\hline $\mathrm{Na}$ taurocholate & $3.0 \mathrm{mg}$ \\
\hline LF & $3.0 \mathrm{ml}$. \\
\hline $\begin{array}{l}\text { Fourteen supplementary solutions } \dagger \\
\mathrm{H}_{2} \mathrm{O} \text { to } \\
\mathrm{pH} \text { adjusted to } 8.0 \text { before autoclavin }\end{array}$ & 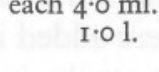 \\
\hline
\end{tabular}

* Cation mixtures, see Table 6.

† Supplementary mixtures (amounts unless otherwise stated in mg per 1.):

D 7: putrecine, IOO; spermine, IOO; choline, 500 .

D 8: niacin, I00; Ca pantothenate, I00; pyridoxine, 20; riboflavin, 5.0; $p$-aminobenzoic acid, Io; inositol, I000.

D9: thiamine, 200; biotin, 0.5; vitamin $\mathrm{B}_{12}, 0.05$; folic acid, $\mathrm{I} \cdot 0$; folinic acid, 0.2 ; thioctic acid, 0.5 .

PPI: guanine, I000; adenine, 500; uracil, 300; thymine, 300 ; cytidylic acid, 300.

AAI: DL-alanine, I0,000; DL-aspartic acid, I0,000; glutamic acid, I0,000; glycine, IO,000.

AA II: L-arginine, I0,000; L-histidine, 5000; DL-lysine, I0,000.

AA III: DL-isoleucine, I000; DL-phenylalanine, I000; DL-leucine, I000; L-tyrosine, rooo.

AAIV: DL-methionine, I000; DL-threonine, 2000; DL-tryptophane, I000.

AA V: DL-serine, 2000; L-proline, rooo; L-valine, rooo.

FAI: $\mathrm{Na}$ acetate (anhyd.), I0,000; butyric acid, $\mathrm{I} \cdot 0 \mathrm{ml}$; propionic acid, $\mathrm{I} \cdot 0 \mathrm{ml}$; ; valeric acid, $\mathrm{I} \cdot \mathrm{O} \mathrm{ml}$.

FA II: succinic acid, I0,000; $\alpha$-ketoglutaric acid, I0,000; fumaric acid, ro,000; malic acid, I0,000.

FA III : pyruvic acid, Io ml.; lactic acid, ro ml.; citric acid, I0,000.

CHHOI: arabinose, I0,000; rhamnose, 10,000; xylose, 10,000; glucose, 10,000; fructose, I0,000; galactose, 10,000; mannose, I0,000.

CHHOII : lactose, 20,000; sucrose, 20,000; maltose, 20,000 . 
In this, glycylglycine acted as $\mathrm{pH}$ buffer, and glycine or histidine as chelating agent in a new trace metal mixture (Io ml. of which contained such amounts of the metals as might occur in I $\mathrm{g}$ of algal protoplasm). The new medium retained the three B vitamin mixtures, the five amino-acid mixtures, SW I, SW 2, potassium nitrate and phosphate, LF, and sodium taurocholate, but glucose was replaced by five solutions embracing a total of 22 carbon compounds.

The quantity of chelator was varied (glycine: 2 , 10 and $100 \mathrm{mg} / 1$; histidine: 4,20 and $200 \mathrm{mg} / 1$.), but after two transfers it was clear that the two lower values of either amino-acid were unsuitable.

A medium with high histidine, S49, was therefore adopted; it is given in full in Table $\mathrm{I}$. This was the first essentially synthetic basal medium to allow more than a couple of transfers. In its 'untailored' state it gave smaller yields than the original E6, but in subsequent transfers, as the essential constituents were identified and brought up to adequate concentration, the yield came to surpass that of the original medium and no component of the latter effected any improvement, although mature cultures lasted rather longer in E 6.

Simplification of this appallingly complex medium was in principle a relatively straightforward undertaking, although it took many months, the work involved being comparatively great.

\section{Carbon source}

Identification of essential carbon sources involved a basal medium lacking the five carbon solutions, FA I-III and CHHO I and II. This medium supported a negligible amount of growth and, moreover, was scarcely improved by the single addition of any one of the carbon solutions (Table 2). But when the solutions were added in pairs (Table 3 ) FA III was shown to be essential and to give best results in combination with FA I, though it was not clear at this stage whether the other solutions also contained available compounds. A breakdown of FA III (Table 4) showed citrate to be the active component of this solution. The active component of FA I was similarly identified as acetate. Citrate, together with a high concentration of acetate, allowed good repeatable growth.

Subsequently no other compound included in solutions FAI-III and CHHOI-II proved to be available as a source of carbon, and the following were also ineffective: glycerol, erithritol, mannitol, sorbitol, dulcitol, raffinose, melizitose, glycogen, starch, inulin, dextrin, salicin and aesculin. Unavailable also was the carbon skeleton of any amino acid included in solutions AA I-V, or of asparagine. Ethanol, however, was utilized and was not toxic at a concentration of $4 \mathrm{ml}$./1. In contrast, propionic, butyric, valeric and lactic acids were toxic in concentrations over $0.04 \mathrm{ml}$. $/ 1$.

By way of confirmation, yield in response to graded doses of sodium acetate, glucose, citric acid, ethanol and valine is shown in Fig. I. The inoculum for 
these cultures had been carried for four transfers in medium $S_{49}$. Citrate thus proved not to be available as a bulk carbon source, whereas acetate served just this purpose since yield appeared as directly proportional to sodium acetate concentrations up to $0.2 \%$. The requirement for citrate is discussed later.

\section{TABLE 2. EFFECT OF SINGLE CARBON SOLUTIONS}

(Basal medium: $\mathrm{S} 49$ with the five carbon solutions omitted. Cells per $\mathrm{mm}^{3}$

\begin{tabular}{|c|c|c|c|c|c|c|}
\hline $\begin{array}{c}\text { No } \\
\text { addition }\end{array}$ & FAI & FAII & FAIII & CHHOI & CHHOII & $\begin{array}{l}\text { All five } \\
\text { solutions }\end{array}$ \\
\hline \multicolumn{7}{|c|}{ First transfer } \\
\hline II & 9 & 9 & I8 & 9 & 8 & 120 \\
\hline \multicolumn{7}{|c|}{ Second transfer } \\
\hline 4 & 2 & 2 & 6 & 5 & 5 & 37 \\
\hline
\end{tabular}

TABLE 3. EFFECT OF CARBON SOLUTIONS IN PAIRS

(Basal medium: S49 with the five carbon solutions omitted. First transfer.

Cells per $\mathrm{mm}^{3}$ after 3 weeks' growth.)

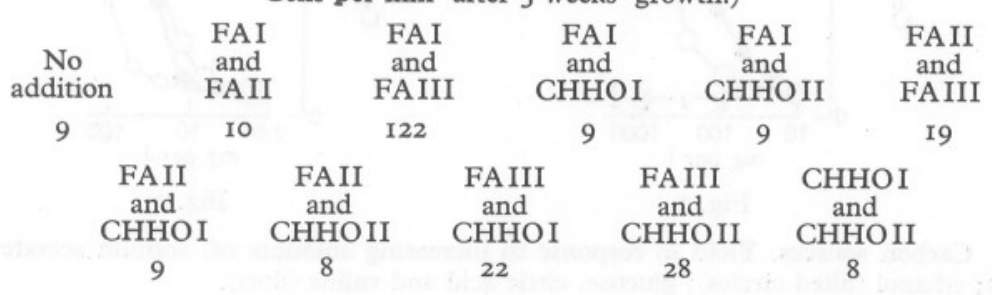

TABLE 4. BREAKDOWN OF FAIII

(Basal medium: S 49 with FAIII omitted. Cells per $\mathrm{mm}^{3}$ after 3 weeks' growth.)

\begin{tabular}{|c|c|c|c|c|c|c|c|}
\hline $\begin{array}{c}\text { No } \\
\text { addition }\end{array}$ & Pyruvate & Lactate & Citrate & $\begin{array}{c}\text { Pyruvate } \\
\text { and } \\
\text { lactate }\end{array}$ & $\begin{array}{c}\text { Pyruvate } \\
\text { and } \\
\text { citrate }\end{array}$ & $\begin{array}{c}\text { Lactate } \\
\text { and } \\
\text { citrate }\end{array}$ & $\begin{array}{c}\text { Pyruvate } \\
\text { and } \\
\text { lactate } \\
\text { and } \\
\text { citrate }\end{array}$ \\
\hline \multicolumn{8}{|c|}{ First transfer } \\
\hline II & 9 & 8 & 89 & 9 & 82 & 69 & 64 \\
\hline \multicolumn{8}{|c|}{ Second transfer } \\
\hline 6 & 5 & 0 & 32 & 3 & 42 & 20 & 26 \\
\hline
\end{tabular}

\section{Nitrogen source}

When amino-acid solutions AAI-V were omitted, medium $\mathrm{S}_{49}$ did not support more than a few cells per $\mathrm{mm}^{3}$ in the first and later transfers. Furthermore, potassium nitrate had no effect on the medium either in the presence of the amino-acids or in their absence and it was subsequently omitted from all media. Oxidized nitrogen is evidently unavailable. 
The single addition of AAI or especially AAV restored the depleted medium, whereas AA II-IV were without effect. A breakdown of AAI and $\mathrm{V}$ showed valine, proline and alanine as active, and aspartic and glutamic acids, glycine and serine as inactive. In later experiments valine proved the most readily available of the three amino-acids and yielded the best dose/response curves, although activity of the other two was of the same order (Fig. 2). No response was obtained to the ammonium ion, which was apparently too toxic at $\mathrm{pH} 8$ to be of any use, nor to urea, uric acid or asparagine.

Valine was therefore adopted as $\mathrm{N}$ source, but a little proline was also retained, as it appeared to be stimulatory in early phases of cultures.

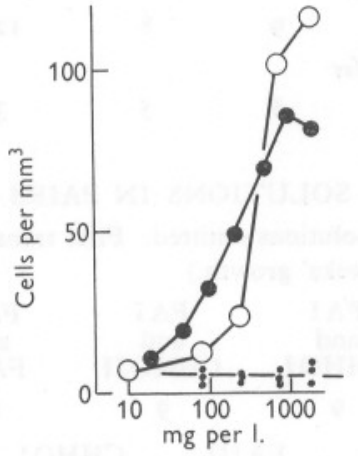

Fig. I

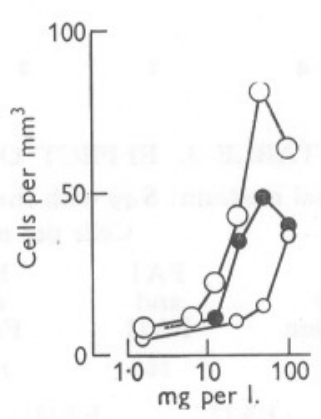

Fig. 2

Fig. I. Carbon sources. Yield in response to increasing amounts of: sodium acetate (open circles); ethanol (filled circles); glucose, citric acid and valine (dots).

Fig. 2. Nitrogen sources. Yield in response to increasing amounts of: valine (large open circles; proline (filled circles); alanine (small open circles).

\section{Growth factors}

In the untailored medium $\mathrm{S}_{49}$ possible growth factors were being supplied in solutions PP I, D 7, D 8 and D9. A conventional process of elimination proved D9 to be the only essential mixture. Similarly, in D9, thiamine, vitamin $\mathrm{B}_{12}$ and biotin proved essential and folic, folinic and thioctic acids unessential. In these analyses it was, of course, necessary to resort to serial transfers, owing to the minuteness of the requirements. The requirements for thiamine and vitamin $\mathrm{B}_{12}$ were absolute, that for biotin possibly not so (Table 5 and Fig. 7).

Dose/response curves for thiamine and vitamin $\mathrm{B}_{12}$ are given in Fig. 3. The thiamine requirement was previously reported in this fournal (Droop, I958); thiazole replaces thiamine completely. Specificity towards the vitamin $\mathrm{B}_{12}$ analogues proved to be of the 'Ochromonas' pattern (Kon, 1955) with the exception that factor A, a natural analogue containing 2-methyl-adenine in place of 4, 6-dimethyl-benzimidazole, showed slight activity in my experiments. 
On the other hand, pseudo-vitamin $\mathrm{B}_{12}$, the analogue containing adenine in the nucleotide, was quite inactive. A similar specificity has been reported by McLaughlin \& Provasoli (I957) for two photosynthetic species of Amphidinium.

TABLE 5. REQUIREMENT FOR VITAMIN $B_{12}$ DEMONSTRATED

BY SERIAL TRANSFERS

(Dose level: $100 \mathrm{~m} \mu \mathrm{g} / 1$. Yield in cells per $\mathrm{mm}^{3}$ )

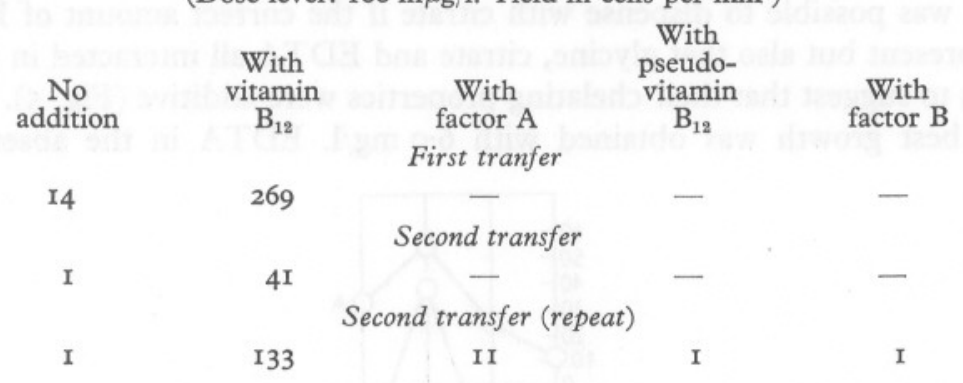

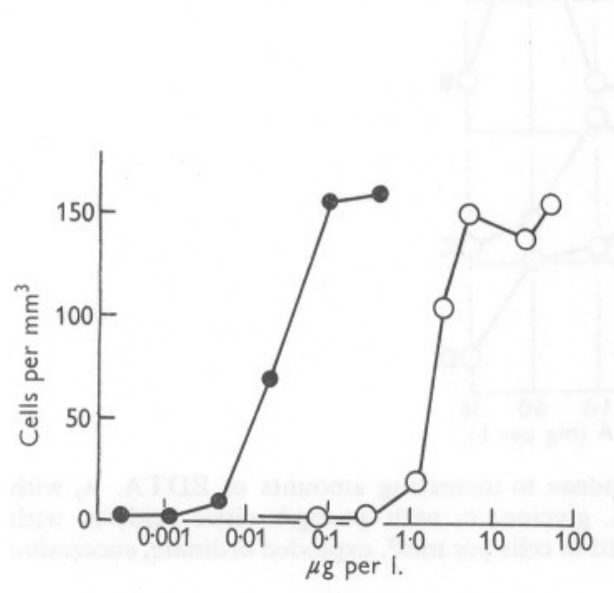

Fig. 3

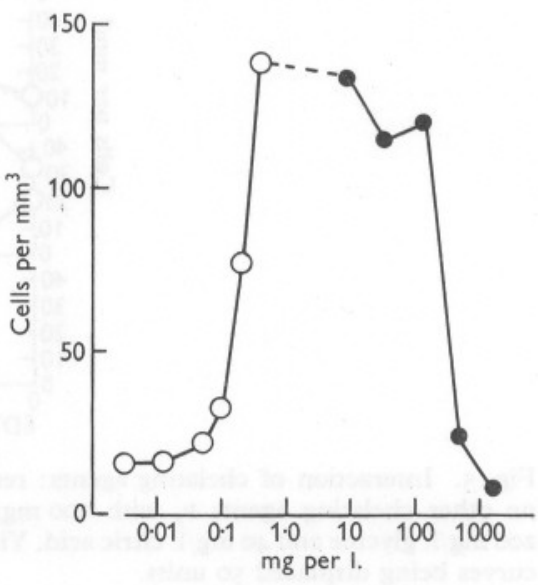

Fig. 4

Fig. 3. Response to increasing amounts of: thiamine (open circles); vitamin $B_{12}$ (filled circles).

Fig. 4. Response to increasing amounts of citric acid (two experiments).

\section{Citric acid}

It was established that citrate, though apparently required, was not available as a bulk carbon source. It might, therefore, be functioning either as a growth factor or as a chelating agent.

Response to graded doses of citrate is shown in Fig. 4. The basal medium contained histidine and the metals of TMII B, but citrate was omitted. The inoculum had passed two passages in citrate-free medium. The response is seen to be sensitive to citric acid concentrations between Io and $100 \mu \mathrm{g} / 1$, while concentrations over $100 \mathrm{mg} / \mathrm{l}$. were toxic. One would suppose that such 
a high order of activity would rule out chelation. However, in another experiment with a medium containing $50 \mathrm{mg} / \mathrm{l}$. EDTA there was no response to citrate at the low end of the scale but growth was uniformly depressed, which suggested that chelation was, after all, involved.

A further set of experiments, undertaken with a basal medium lacking both citrate and histidine but containing the trace metals of TM I I B, not only showed that it was possible to dispense with citrate if the correct amount of EDTA were present but also that glycine, citrate and EDTA all interacted in such a way as to suggest that their chelating properties were additive (Fig. 5). Thus, while best growth was obtained with $6.0 \mathrm{mg} / 1$. EDTA in the absence of

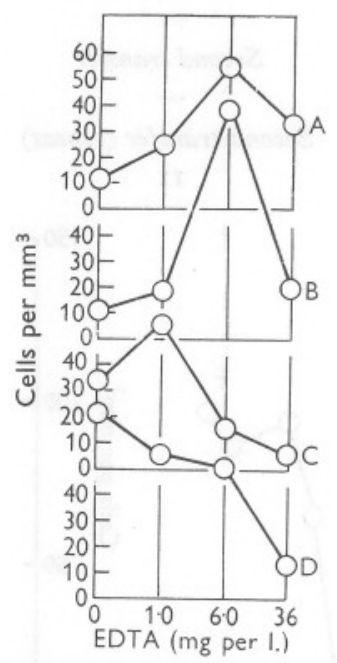

Fig. 5. Interaction of chelating agents: response to increasing amounts of EDTA. A, with no other chelating agent; B, with $200 \mathrm{mg} / 1$. glycine; C, with $40 \mathrm{mg} / 1$. citric acid; D, with $200 \mathrm{mg} / \mathrm{l}$. glycine and $40 \mathrm{mg} /$. citric acid. Yield in cells per $\mathrm{mm}^{3}$, exploded ordinate, successive curves being displaced 50 units.

citrate, in its presence ( $40 \mathrm{mg} / \mathrm{l}$. citric acid) only $\mathrm{I} \cdot 0 \mathrm{mg} / \mathrm{l}$. EDTA was required. Furthermore, with citrate and glycine both in the medium no EDTA was required.

The apparent requirement for citrate is thus seen to be due to inadequate chelation by glycine or histidine. The fact that the ferric ion forms no complex with $\alpha$-amino acids (Albert, 1950) should have made this conclusion obvious; indeed, in the absence of both citrate and EDTA a precipitate, which could be iron hydroxide, forms in the medium upon autoclaving.

On the other hand, the reason for poor growth in media with high (20-60 $\mathrm{mg} / 1$.) EDTA is not at all clear. Over-chelation is ruled out because calculation $^{1}$ shows the concentrations of the free ions of each of the metals in the

\footnotetext{
1 By a method suggested by Spencer (1958), with the aid of published stability constants.
} 
mixture actually to be lower with the citrate-glycine or histidine mixtures than with even the highest concentrations of EDTA used. EDTA may indeed be toxic to Oxyrrhis for some entirely unconnected reason.

It is possible, however, to conclude empirically, that in a half-strength artificial sea-water medium with cationic concentrations as shown in Table 6, and in which the strongest chelators otherwise are valine and glycylglycine, the main function of chelation can be discharged by a variety of combinations of EDTA, citrate and glycine or histidine, bearing in mind that glycine and histidine do not chelate trivalent iron and that EDTA behaves as if it were inherently toxic.

\section{$\mathrm{pH}$ control}

The use of synthetic media introduces an urgent need for $\mathrm{pH}$ control, for a great many variables are influenced by $\mathrm{pH}$. In particular, the degree of ionization and penetration of weak acids, bases and amphoteric substances is affected and consequently their utilization or toxicity. $\mathrm{pH}$ also enters as a term in the mass-action equations controlling the behaviour of heavy metals with chelating agents and on that account may not be ignored. It can be said with truth that a synthetic culture medium must be developed in relation to, and may only be useful over, a limited $\mathrm{pH}$ range.

$\mathrm{pH}$ control during growth does not present great problems except in certain circumstances. But the act of autoclaving a culture medium does create difficulties. Permanent damage may be done to a medium in which $\mathrm{pH}$ buffering is left to the carbonate-bicarbonate system, because the great rise in $\mathrm{pH}$ occasioned by the loss of carbon dioxide causes uncontrolled, usually irreversible, precipitation of various components. However, the practice of incorporating artificial buffers overcomes this difficulty to a large extent (Provasoli et al. 1957).

Since one seeks to prevent $\mathrm{pH}$ rise during autoclaving, the region where high buffer capacity is needed is immediately and for some distance above the setting. Thus, for a setting of $\mathrm{pH} 8$, media buffered with glycylglycine $\left(\mathrm{p} K_{2}=8 \cdot \mathrm{I}\right)^{1}$ should be improved by the presence of compounds having higher $\mathrm{p} K$ values. Valine $\left(\mathrm{p} K_{2}=9.6\right)$, histidine $\left(\mathrm{p} K_{2}=9.7\right)$ or glycine $\left(\mathrm{p} K_{2}=9 \cdot 7\right)$ serve this purpose in addition to their other functions (Fig. 6).

There are, however, valid objections to the use of organic acids in culture media on the grounds that they complicate the situation needlessly. Some $\mathrm{pH}$ buffers are also chelating agents; many of them (e.g. glycylglycine) are weak and can be ignored in adequately balanced media, but others have considerable influence and must be taken into account, as has been done in the case of histidine and glycine in the previous section. It is also undesirable that substances introduced for their physical effects should be metabolized, and due account should be taken of this possibility in any instance. But the

\footnotetext{
1 The relatively more toxic TRIS buffers in the same region.
} 
converse is equally true: the physical properties of compounds introduced as nutrients cannot always be ignored.

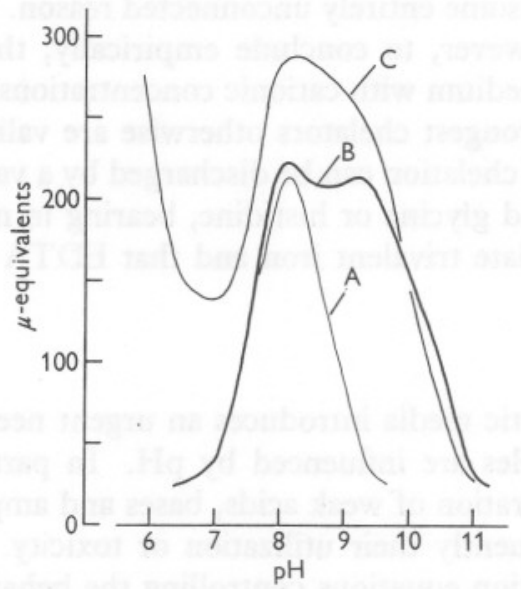

Fig. 6. Buffer capacity of some culture media in $\mu$-equivalents of acid or alkali required to displace $\mathrm{pH}$ by $0 . \mathrm{I}$. A, media with $3.8 \mathrm{~mm}$ glycylglycine or TRIS alone (e.g. $\mathrm{S}_{36}$, Provasoli et al. 1957); B, media with $3.8 \mathrm{~mm}$ glycylglycine and $3.3 \mathrm{~mm}$ glycine (e.g. S 50, Droop, I958); c, media with $3.8 \mathrm{~mm}$ glycylglycine, $\mathrm{I} \cdot 3 \mathrm{~mm}$ histidine, $2.1 \mathrm{~mm}$ valine and $25 \mathrm{~mm}$ acetic acid (S69, Table 6). (Based on data from the 'Bufferule' by the California Corporation for Biochemical Research.)

\section{FINAL MEDIUM}

The conclusions expressed in the previous pages are embodied in the two 'final' media S68 and S69 set out and annotated in Table 6. If handled carefully Oxyrrhis maintains heavy yields on continued subculturing in S69 (Fig. 7); consequently it is likely that all absolute water-soluble requirements are now defined. ${ }^{1}$

In Fig. 8 a typical growth curve in $\mathrm{S} 69$ and one in $\mathrm{OX}_{7}$ (a maintenance medium $^{2}$ ) are contrasted with growth on living Saccharomyces exiguus (Droop, 1959). The contrast is sufficiently striking and is in a sense a measure of failure to substitute a non-living for a living diet. In this connexion it should be mentioned that although whole milk, egg yolk and lipids such as olive, linseed and palm oils can be ingested none have been found which improve the rate of growth or replace acetic acid. It would appear to be a living diet and not phagotrophy per se which makes for the high growth rate (Droop, I953b).

Two further characteristics of axenic cultures which have been responsible for many delays and frustrations in this investigation are the inability of

${ }_{1}^{1}$ Proline and histidine have now also been rigorously eliminated from the list of possible absolute requirements.

${ }^{2}$ One litre of $\mathrm{OX}_{7}$, which is now recommended for maintenance of axenic stocks, contains: Bacto Casitone, $125 \mathrm{mg}$; soil extract, $30 \mathrm{mg}$; $\mathrm{Na}$ acetate, $2 \mathrm{~g}$; valine, $250 \mathrm{mg}$; D9 vitamins, $20 \mathrm{ml}$; $\mathrm{K}_{2} \mathrm{HPO}_{4}$, IO mg; LF, $3 \mathrm{ml}$; natural sea water, $500 \mathrm{ml}$. 
isolated cells to multiply, even in media which support normal subculturing indefinitely, and the inability of a population whose growth has been arrested by nutritional depletion to pick up again on being transferred to a complete

TABLE 6. MEDIA S68 AND S69

(Amounts per 1.; $\mathrm{pH}$ adjusted to 8.0 before autoclaving.

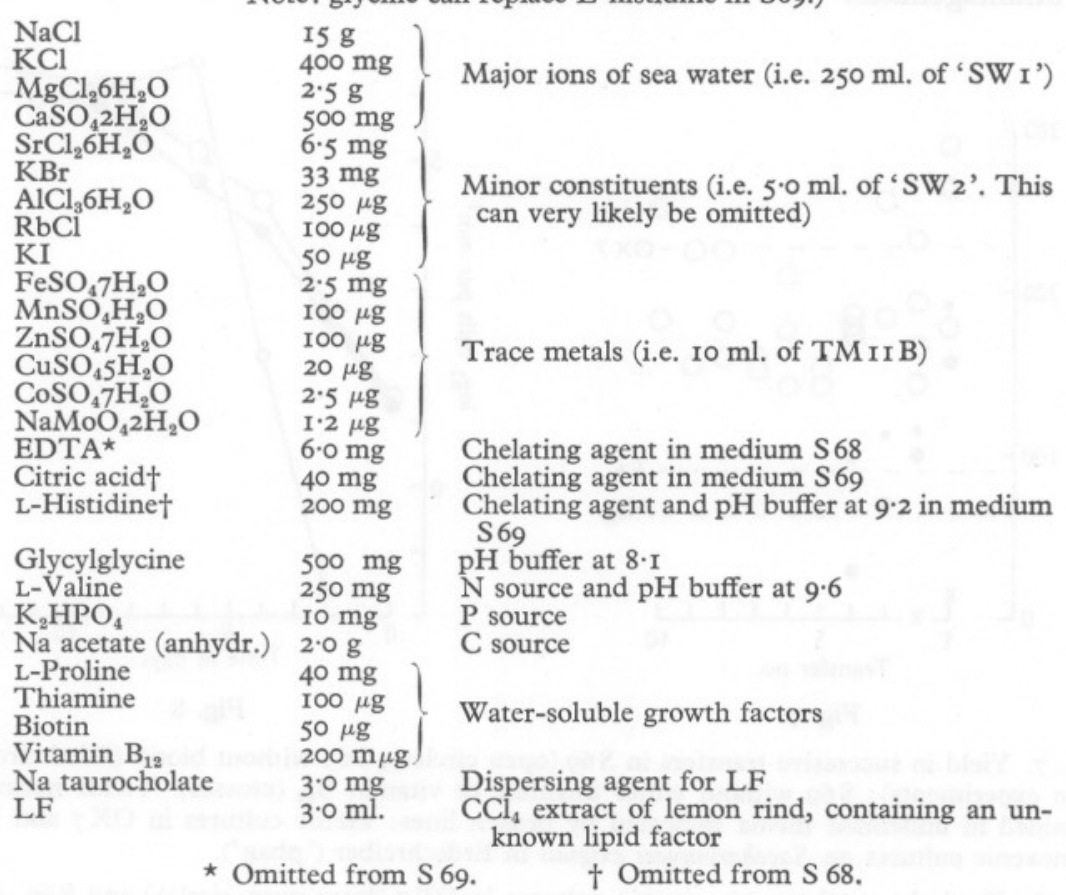

medium. The rate of growth once depressed may stay so over many transfers, or even indefinitely. As can be imagined, these characteristics render the serial subculturing technique extremely difficult to handle. I am of the opinion that the explanation of this behaviour will prove to lie with the lipid factor and not the water-soluble nutrients, but one cannot be sure. However, no aqueous extract or hydrolysate of natural materials yet tried has been of any avail; and filter-sterilizing crude media to avoid destroying heat-labile substances has likewise been useless.

\section{NUTRITIONAL STATUS}

Dinophyceae have since Pascher(I9I4) and Fritsch (1935) been generally recognized as one of the great algal series; albeit one represented almost entirely by motile unicells. ${ }^{1}$ They are not alone among algae in having phagotrophic

1 The possible affinity of $O$. marina with the Cryptophyceae (Dragesco, 1952) emphasizes Pascher's views regarding the near relationship between the two series. 
representatives; this character they share with Euglenophyceae and Chrysophyceae. Starch staining blue with iodine is among the reserve products, though in my experience in many species, including Oxyrrhis marina, starch is only found in the cysts. Lwoff (1944, p. 215) and Hutner \& Provasoli (I955, p. I9), however, stress the animal or protozoan tendencies shown by dinoflagellates.

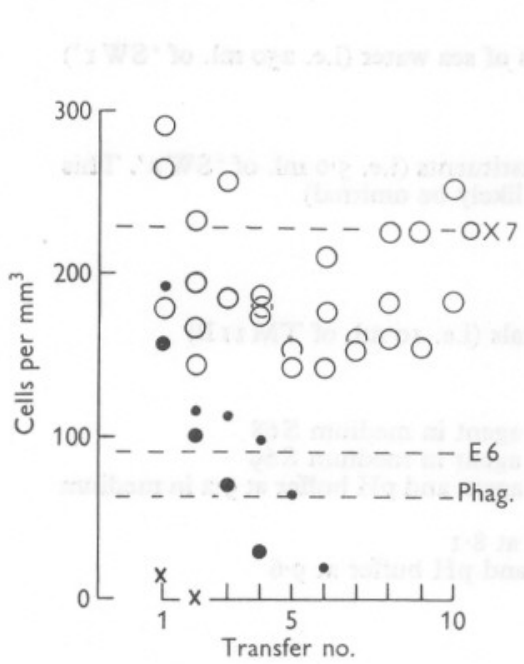

Fig. 7

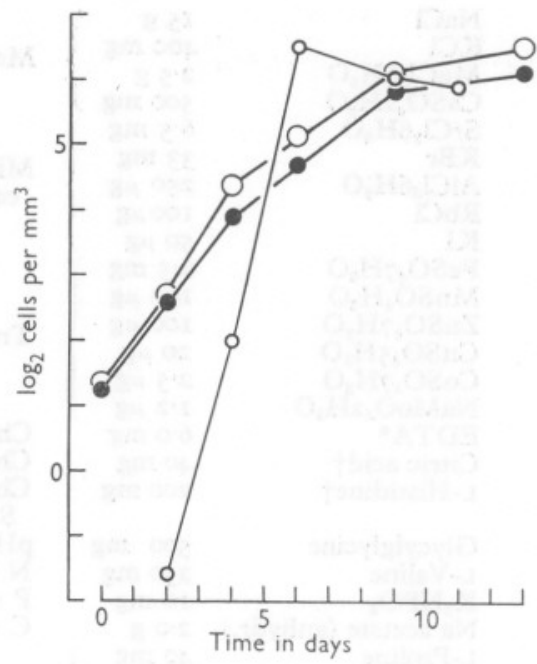

Fig. 8

Fig. 7. Yield in successive transfers in S69 (open circles); S69 without biotin (filled circles) (two experiments); $\mathrm{S} 69$ without either thiamine or vitamin $\mathrm{B}_{12}$ (crosses). Yields normally obtained in undefined media indicated by broken lines: axenic cultures in $\mathrm{OX}_{7}$ and E6; monoxenic cultures on Saccharomyces exiguus in Erdschreiber ('phag').

Fig. 8. Typical growth curves: axenic cultures in $\mathrm{OX}_{7}$ (large open circles) and S69, Ioth transfer (filled circles); monoxenic cultures on Saccharomyces exiguus in Erdschreiber (small open circles).

Superficially Oxyrrhis has an entirely animal-like nutrition, for it can rely, and probably does so in nature, on phagotrophy for all its major and accessory nutrients. Only when phagotrophy is denied it and an analysis then made of its nutritional requirements and abilities does a more plant-like nature emerge.

Taking carbon nutrition first: Oxyrrhis proves to be an 'acetate flagellate' (Pringsheim, I935; Pringsheim \& Hovasse, I948; Hutner \& Provasoli, I95I) since it uses acetic acid and ethanol, not glucose nor the carbon of aminoacids, for growth. Lwoff (1944) termed this kind of nutrition 'oxytrophy' in contrast to the 'haplotrophy' of organisms that use a wider range of substrates. ${ }^{1}$ Lwoff's designations 'chlorophyte', 'leucophyte', 'protozoon',

1 These are subdivisions of what Lwoff called 'allotrophy', but now more generally known as chemotrophy. 
broadly correspond to the respective nutritional categories phototroph, oxytroph, haplotroph. However, a great many chlorophytes are oxytrophic in the dark while many others, including isolated tissues of phanerogams, utilize carbohydrate as well and to that extent may be regarded as being haplotrophic (Provasoli, I938; Algeus, 1946; White, I95I; Pringsheim, 1952; Lewin, 1953). Although the number of possible substrates is even greater in animals such as ciliates, insects and vertebrates, so it is also in some fungi and bacteria (Kidder \& Dewey, 195I ; Trager, I953; Albritton, I954; Foster, 1949; Stephenson, 1949).

Acetate organisms are thus characterized by limitations which they share with neither animals nor higher plants. They would not, therefore, appear to be in direct evolutionary line with plants or animals, which are probably derived from more versatile ancestors. The limitation according to current views (Lwoff, I95I) is probably one of phosphorylating enzymes rather than membrane permeability. Limited permeability is implied, however, in the resistance shown by many acetate flagellates to high concentrations of such penetrating and toxic substrates as acetic acid and ethanol, or, for that matter, to their typically highly polluted habitat (Hutner \& Provasoli, I95I).

As regards nitrogen nutrition: although ability to employ nitrate as sole nitrogen source is confined to the plant kingdom, loss of the ability is found in some members of most phyla of plants. Oxyrrhis shares this state of slight but obligate heterotrophy (mesotrophy) with such photosynthetic algae as Hemiselmis virescens (Cryptophyceae) and Chlamydomonas pulsatilla (Chlorophyceae). Here nitrogen requirements are met by the ammonium ion or, failing that, any one of a number of simple organic compounds provided they can be made to yield an amino group. In fungi and bacteria greater and varying degrees of heterotrophy are to be found; they are exemplified by specific requirements for one or more amino-acids (Snell, 195I). But it is in animals (ciliates, insects, vertebrates) that nitrogen heterotrophy has proceeded farthest and become so stereotyped that it is possible to speak of the 'ten amino acids essential for protein synthesis' with little ambiguity (Kidder \& Dewey, I951; Trager, I953; Rose, 1938). Against this background the mere inability to reduce nitrate would seem not to remove Oxyrrhis very far from the higher green plant.

Oxyrrhis requires but thiamine, vitamin $\mathrm{B}_{12}$ and biotin among $\mathrm{B}$ vitamins, thus showing a self-sufficiency toward the remainder that is typical of auxotrophic lower algae (Droop, 1957; Provasoli, 1958). Provasoli (1957) regards auxotrophy as indicating 'animality' ('vegetality' being typified by the need for plant hormones). Certainly, the lower members of the plant kingdom are likely to be more animal-like than the higher ones. On the other hand, many isolated phanerogamic tissues are also auxotrophic; fungi are commonly so. Even a vitamin $\mathrm{B}_{12}$ requirement is now recorded in a fungus (Adair \& Vishniac, I958) and in tumour tissues of spruce (Reinert \& White, 1956). Furthermore, 
the pattern of specificity towards the vitamin $B_{12}$ analogues typical of vertebrates and, by inference therefore, the most animal-like of the three patterns, is also shown by all the Chlorophyceae requiring vitamin $\mathrm{B}_{12}$ which $\mathrm{I}$ have examined. ${ }^{1}$

One is struck by the simplicity of the growth requirements in Oxyrrhis. But for the 'lemon factor' which in truth has been responsible for past failures with this organism, it is a typical acetate flagellate with an acetate flagellate's requirements and abilities, no more and no less plant-like. Phagotrophy thus emerges as an anomalous element in a conventional nutritional pattern. A progression phototroph-oxytroph-phagotroph could now be put beside the more usual (though equally theoretical) sequence phototrophhaplotroph-phagotroph. Such a progression might be characteristic of dinoflagellates and euglenids, but our knowledge is scanty. Although oxytrophy is well documented in the latter, the principal substrate for phagotrophic members is unknown (Storm \& Hutner, I953); and the only other nonphotosynthetic dinoflagellate being studied is Gyrodinium cohnii for which there are as yet no published data. ${ }^{2}$

Phagotrophy appears to be commoner than saprotrophy in colourless dinoflagellates; photosynthetic phagotrophs are also reported. This might mean that in this alliance phagotrophy usually arises before the loss of photosynthetic pigments. It is also likely to have preceded the advent of any lipid requirements, which would otherwise be greatly disadvantageous to a freeliving aquatic organism. Conversely, such requirements would survive without hindrance in established phagotrophs, with the result that their lipid metabolism would tend in the long run to become atrophied. On the other hand, organisms as large as Oxyrrhis have relatively limited cell surface, and are likely to find phagotrophy the most efficient method of feeding-particularly in nutritionally depleted environments. Isolation has many advantages; its disadvantages are thus avoided. An acetate organism which is also a phagotroph gets indeed the best of both worlds.

\section{SUMMARY}

The phagotrophic dinoflagellate Oxyrrhis marina can be cultivated indefinitely in the absence of other organisms of all kinds provided it is supplied with certain vegetable lipids.

Development of culture media in which all the water-soluble components are defined enabled the water-soluble nutrient and absolute growth factor requirements to be ascertained. The media were equivalent to a half-strength sea water buffered with glycylglycine and histidine with a trace metal mixture chelated with histidine and citrate.

${ }^{1}$ Balticola droebakensis, B. buetschlii, Brachiomonas submarina, Chlamydomonas pulsatilla, Platymonas tetrathele and Stephanosphaera pluvialis.

2 Dr L. Provasoli, however, tells me that glucose is utilized by G. cohnii. 
Acetate or ethanol (not any carbohydrate nor the carbon of amino-acids) serve as carbon source, and alanine, proline or especially valine (not $\mathrm{NO}_{3}{ }^{-}$, $\mathrm{NH}_{4}{ }^{+}$or urea or other amino-acids) as nitrogen source. Auxotrophic requirements are met by the thiazole moiety of thiamine, vitamin $\mathrm{B}_{12}$ (near 'Ochromonas' specificity), and biotin.

The nutritional status of Oxyrrhis marina is discussed.

\section{REFERENCES}

AdAIR, E. J. \& VishnIAC, H. S., I958. Marine fungus requiring Vitamin $\mathrm{B}_{12}$. Science, Vol. I27, pp. I47-8.

ALBERT, A., I950. Quantitative studies of the avidity of naturally occurring substances for trace metals. I. Amino-acids having only two ionizing groups. Biochem. F., Vol. 47 , pp. 53I-8.

Albritton, E. C., 1954. Standard Values in Nutrition and Metabolism. 380 pp. Philadelphia: W. B. Saunders Co.

ALgEUS, S., 1946. Untersuchungen über die Ernährungsphysiologie der Chlorophyceen. Bot. Notiser, 1946, pp. I-278.

BARKER, H. A., I935. The culture and physiology of the marine dinoflagellates. Arch. Mikrobiol., Vol. 6, pp. I57-81.

Dragesco, J., 1952. Le flagellé Oxyrrhis marina: cytologie, trichocysts, position systématique. Bull. microscop. App., Ser. 2, Vol. 2, pp. I48-57.

Droop, M. R., I953a. On the ecology of flagellates from some brackish and freshwater rockpools of Finland. Acta bot. fenn., Vol. 51, pp. I-52.

- 1953b. Phagotrophy in Oxyrrhis marina Dujardin. Nature, Lond., Vol. 172, p. 250.

1957. Auxotrophy and organic compounds in the nutrition of marine phytoplankton. F. gen. Microbiol., Vol. 16, pp. 286-93.

1958. Requirement for thiamine among some marine and supra-littoral protista. F. mar. biol. Ass. U.K., Vol. 37, pp. 323-9.

- 1959. A note on some physical conditions for cultivating Oxyrrhis marina. f. mar. biol. Ass. U.K., Vol. 38, pp. 599-604.

Foster, J. W., I949. Chemical Activities of Fungi. 648 pp. New York: Academic Press Inc.

Fritsch, F. E., 1935. The Structure and Reproduction of the Algae. Vol. I, 791 pp. Cambridge University Press.

Hutner, S. H. \& Provasoli, L., I95I. The phytoflagellates. In Biochemistry and Physiology of Protozoa, Vol. I, pp. 27-128. Ed. A. Lwoff. New York: Academic Press Inc.

- 1955. Comparative biochemistry of flagellates. In Biochemistry and Physiology of Protozoa, Vol. 2, pp. 17-44. Ed. S. H. Hutner and A. Lwoff. New York: Academic Press Inc.

KIDDER, W. G. \& DEWEY, V. C., I95I. The biochemistry of ciliates in pure culture. In Biochemistry and Physiology of Protozoa, Vol. I, pp. 323-400. Ed. A. Lwoff. New York: Academic Press Inc.

Kon, S. K., I955. Other factors related to vitamin $\mathrm{B}_{12}$. Symp. biochem. Soc., No. 13, pp. $17-35$.

LewIN, J. C., I953. Heterotrophy in diatoms. F. gen. Microbiol., Vol. 9, pp. 305-13.

Lwoff, A., I944. L'évolution physiologique. 308 pp. Paris: Hermann et Cie.

I95I. Introduction to biochemistry of protozoa. In Biochemistry and Physiology of Protozoa, Vol. I, pp. I-26. Ed. A. Lwoff. New York: Academic Press Inc. 
McLaughin, J. J. A. \& Provasoli, L., I957. Nutritional requirements and toxicity of two marine Amphidinium. F. Protozool., Vol. 4, Suppl. p. 7.

Pascher, A., 19I4. Ueber Flagellaten und Algen. Ber. dtsch. bot. Ges., Bd. 32, pp. 136-60, 430.

Pringsheim, E. G., 1935. Über Azetatflagellaten. Naturwissenschaften, Bd. 23, pp. IIO-I4.

1952. On the nutrition of Ochromonas. Quart. F. micr. Sci., Vol. 93, pp. 71-96.

Pringsheim, E. G. \& Hovasse, R., I948. The loss of chromatophores in Euglena gracilis. New Phytol., Vol. 47, pp. 52-87.

Provasoli, L., I938. Studi sulla nutrizione dei protozoi. Boll. Zool. agr. Bachic., Vol. 9, pp. I-I24.

- 1957. Alcune considerazioni sui caratteri morfologici e fisiologici delle alghe. Boll. Zool. agr. Bachic., Vol. 22, pp. I43-88.

- 1958. Nutrition and ecology of protozoa and algae. Annu. Rev. Microbiol., Vol. I2, pp. 279-308.

Provasoli, L., Mclaughlin, J. J. A. \& Droop, M. R. 1957. The development of artificial media for marine algae. Arch. Mikrobiol., Bd. 25, pp. 392-428.

REINERT, J. \& WHITE, P. R., I956. The cultivation in vitro of tumor tissues and normal tissues of Picea glauca. Physiol. Plant., Vol. 9, pp. 177-89.

Rose, W. C., 1938. The nutritive significance of the amino-acids. Physiol. Rev., Vol. 18, pp. 109-36.

SNELL, E. E., I95I. Bacterial nutrition-Chemical factors. In Bacterial Physiology, pp. 215-56. Ed. C. W. Werkman and P. W. Wilson. New York: Academic Press Inc.

SPENCER, C. P., 1958. The chemistry of ethylenediamine tetra-acetic acid in sea water. F. mar. biol. Ass. U.K., Vol. 37, pp. 127-44.

Stephenson, M., 1949. Bacterial Metabolism. 398 pp. 3rd edition. London: Longmans, Green and Co.

Storm, J. \& Hutner, S. H., 1953. Nutrition of Peranema. Ann. N.Y. Acad. Sci., Vol. 56, pp. 90I-9.

Trager, W., I953. Nutrition. In Insect Physiology, pp. 350-86. Ed. K. D. Roeden. London: Chapman and Hall.

White, P. R., I95I. Nutritional requirements of isolated plant tissues and organs. Annu. Rev. Pl. Physiol., Vol. 2, pp. 23I-44. 